\title{
DUALISMO CARTESIANO: PROBLEMAS GERADOS NA FORMAÇÃO DO CONCEITO
}

\author{
$\underline{\text { Jezer Hezrom Lima de Oliveira }}{ }^{1}$; José Portugal dos Santos Ramos ${ }^{2}$ \\ 1. Bolsista PIBIC/CNPq, Graduando em Psicologia, Universidade Estadual de Feira de Santana, e-mail: \\ jezeroliveira1@gmail.com \\ 2. Orientador, Departamento de Ciências Humanas e Filosofia, Universidade Estadual de Feira de Santana, e-mail: \\ domluso@gmail.com
}

PALAVRAS-CHAVE: Dualismo; Descartes; Cottingham.

\section{INTRODUÇÃO}

René Descartes estrutura seu sistema filosófico e sedimenta suas bases metafisicamente a partir de sua obra Meditationes de Prima Philosophia (Meditações sobre a filosofia primeira) publicada em Paris no ano de 1641. Nela o filosofo apresenta duas substâncias distintas, res cogitans e res extensa, reconhece o atributo e as faculdades de cada uma delas, e percebe que duas faculdades particulares do pensamento (cogito), a sensação e a imaginação, não são imputáveis somente a substância pensante mas que surgem da relação com a substância extensa. Partindo desse problema, o comentador inglês Jonh Cottingham argumenta que para uma melhor compreensão da filosofia cartesiana devemos admitir a possibilidade de uma terceira substância. $\mathrm{O}$ objetivo desta pesquisa é expor a argumentação de Cottingham e demonstrar a viabilidade da proposta deste comentador, além de demostrar se há outras possibilidades de se esclarecer tal questão.

\section{MATERIAL E MÉTODOS OU METODOLOGIA (ou equivalente)}

O método utilizado foi fundamentalmente teórico tendo como referência primária algumas obras escritas por Descartes, em especifico algumas partes destas obras que tratam sobre a questão do método e cogito, e em obras secundárias, escritas por comentadores do Descartes com o intuito de avaliar outras interpretações sobre o tema proposto bem como elucidar algumas questões, facilitando desta forma o entendimento do autor.

Estando a participar do Grupo de Estudos "Revoluções científicas nos séculos XVI e XVII: origens e ressonâncias do método proposto por Descartes em 1637", que se constituí pela equipe de professores em conjunto com alunos de iniciação científica e alunos voluntários que se interessem em seguir uma rotina de produção de conhecimento sobre os temas relativos a este projeto. A frequência ao grupo me proporcionou orientação especializada, críticas e sugestões facilitando o desenvolvimento e conclusão da pesquisa em tempo hábil. A execução da pesquisa contou com a infraestrutura do NEFIUEFS, de maneira que não necessitei de recursos financeiros. Em relação ao material bibliográfico indispensável à pesquisa, foi adquirido com recursos do próprio coordenador do projeto ou acessado à Biblioteca da UEFS.

\section{RESULTADOS E/OU DISCUSSÃO (ou Análise e discussão dos resultados)}

O conceito de dualismo cartesiano gera muitos problemas quando partimos para a questão da interação entre as substâncias, e um desses problemas, o que vai ser considerado aqui são as faculdades que surgem da relação entre substâncias. Para além, serão analisadas as diferentes interpretações dadas pelos comentadores e suas propostas de soluções ao problema de interação entre tais substâncias. O comentador utilizado com o propósito de 
exemplificar o objetivo aqui pretendido foi o autor de língua inglesa, John Cottingham, com sua proposta de uma nova categoria no conceito acima citado, ao qual ele chama de Trialismo Cartesiano.

Diante de um conhecimento constituído de falsas opiniões, as quais eram frequentemente tomadas como verdadeiras, Descartes, em sua obra Meditações Sobre Filosofia Primeira (Meditationes de Prima Philosophia), publicada em 1641, se propõe a examinar e fazer ruir os alicerces sobre os quais o edifício desse conhecimento está construído, a fim de, após isso, se lançar a procura de uma certeza que lhe permita construir algo de firme e constante nas ciências.

De maneira metódica, ele começa a desfazer-se de tudo aquilo que lhe suscite a menor dúvida, e na busca de encontrar algo que se mostre inteiramente indubitável, Descartes estende a dúvida desde o conhecimento que obtém através dos sentidos, até o conhecimento de noções simples e universais, como as de que se ocupam as ciências Aritméticas e da Geometria. Nesse ponto surge um argumento que leva a dúvida à sua extensão máxima - e se existe um Gênio Maligno que o engana todo o tempo e se faz uso de todo o seu poder com esse propósito? Com a chegada do limite da dúvida ele levanta a seguinte reflexão:

Mas que sei eu, se não há nenhuma outra coisa diferente das que acabo de julgar incertas, da qual não se possa ter a menor duvida? Não haverá nenhum Deus, ou alguma outra potência, que me ponha no espírito tais pensamentos? Isso não é necessário; pois talvez eu seja capaz de produzi-los por mim mesmo. (DESCARTES, 1979, p. 91).

E conclui que:“[...] eu existia sem dúvida, se é que me persuadi, ou, apenas, pensei alguma coisa.”(DESCARTES, 1979, p. 92).

Após obter a primeira certeza, "Eu sou, eu existo", Descartes se põe a examinar o que ele é, e se põe a repassar tudo o que ele anteriormente tomava por si, com o propósito de verificar se dessas coisas há algo que possa pertencer inteiramente a seu ser. Repassando os atributos da alma e encontrado um que o pertence realmente, o pensamento, que não é distinguível de sua essência:

Eu sou, eu existo: isto é certo; mas por quanto tempo? A saber, por todo o tempo em que eu penso; pois poderia, talvez, ocorrer que, se eu deixasse de pensar, deixaria ao mesmo tempo de existir. Nada admito agora que não seja necessariamente verdadeiro: nada sou, pois, falando precisamente, senão uma coisa que pensa, isto é, um espírito, um entendimento ou uma razão, que são termos cuja significação me era anteriormente desconhecida. (DESCARTES, 1979, p. 94).

O reconhecimento do atributo dessa essência não implica o conhecimento completo da existência que se está a investigar, isto leva Descartes a continuar conduzindo seu espírito, para que ele conceba o que mais se pode conhecer de sua existência. Na sequência da meditação ele reconhece as faculdades pelas quais a coisa pensante (res cogitans) se manifesta:

Mas que sou eu, portanto? Uma coisa que pensa. Que é uma coisa que pensa? É uma coisa que duvida, que concebe, que afirma, que nega, que quer, que não quer, que imagina também e que sente. (DESCARTES, 1979, p. 95).

Esse trecho das Meditações é o que possibilita ao comentador John Cottingham o início da sua argumentação. 


\section{CONSIDERAÇÕES FINAIS (ou Conclusão)}

No âmbito da filosofia, a pesquisa proporciona uma maior profundidade e amplitude de visão no que se refere ao pensamento cartesiano e a influência de suas ideias para a filosofia metafísica e ciência moderna.

\section{REFERÊNCIAS}

Fontes primárias (obras de Descartes):

DESCARTES, René. Oeuvres de Descartes. Paris: Librairie Philosophique J. Vrin. 1996. 11 vol. Publiées par Charles Adam e Paul Tannery.

Pensadores"). . Meditações Metafísicas, São Paulo, Abril Cultural, 1979, (Coleção “Os Princípios da Filosofia. São Paulo: Folha de S. Paulo, 2010.

Obras secundárias:

ALQUIÉ, Ferdinand. A Filosofia de Descartes. Tradução de Rodrigues Martins. Lisboa: Editorial Presença, 1986.

AUBENQUE, P. La transformation cartésienne du concept aristotelicien de substance. Paris: Les Belles Lettres, 2002.

BEYSSADE, Jean-Marie. Études sur Descartes. Paris: Éditions du Seuil, 2001.

BEYSSADE, Michelle. Descartes. Tradução de João Gama. Lisboa: Edições 70, 1989.

COTTINGHAM, John. A filosofia de Descartes. Lisboa: Edições 70, 1989.

218-230. . Cartesian Trialism. Mind, New Series, vol. 94, nº 374 (abril, 1985), pp. Jorge Zahar Editor, 1993.

Dicionário Descartes. Tradução de Helena Martins. Rio de Janeiro:

GARBER, Daniel. Descartes and Occasionalism. In: Descartes Embodied: reading Cartesian philosophy through Cartesian science. Cambridge: Cambridge University Press, 2001b. p. 203-220

GUEROULT, Martial. Descartes Selon L’Ordre des Raisons. Paris: Aubier. I e II , 1968. 